\section{SOI: 1.1/TAS DOI: $10.15863 / \mathrm{TAS}$ International Scientific Journal Theoretical \& Applied Science}

p-ISSN: 2308-4944 (print) e-ISSN: 2409-0085 (online)

Year: 2015 Issue: 12 Volume: 32

Published: $30.12 .2015 \quad$ http://T-Science.org
Abdinazar Tashbajevich Nurmanov

Ph.D, senior researcher, Tashkent State Pedagogical University named after Nizami, Uzbekistan anurmanovjizzax@mail.ru

SECTION 21. Pedagogy. Psychology. Innovation in Education.

\title{
TECHNOLOGICAL ASPECTS OF STUDENTS TRAINING TO EFFECTIVE COMMUNICATION AT PEDAGOGICAL UNIVERSITY
}

Abstract: The article reveals the problems of future teachers training to effective communication with the consideration of modern tendencies development and implementation of subject - subject interactions at pedagogical institutions. The necessity of studying this problem was dictated by the practice of the educational process at pedagogical institutions of the Republic, where insufficient attention is paid to the development and improvement of students' communicative competence. There were proposed the technology of students training to effective communication and its potency was experimentally proved.

Key words: effective communication, effective communication technology, communicative competence, communicative culture, criteria of effective communication, pedagogical communication.

Language: English

Citation: Nurmanov AT (2015) TECHNOLOGICAL ASPECTS OF STUDENTS TRAINING TO EFFECTIVE COMMUNICATION AT PEDAGOGICAL UNIVERSITY. ISJ Theoretical \& Applied Science 12 (32): 81-86.

Soi: http://s-o-i.org/1.1/TAS-12-32-15 Doi: crossef http://dx.doi.org/10.15863/TAS.2015.12.32.15

\section{UDC 378.01}

Modern social-economic conditions actualizes the enhancement of training qualified specialists possessing innovational ideology, "characterized by readiness to changes, pluralism of views, orientation to information" [1, p.4], willingness to continuous education and professional development, skill of projecting and self-projecting results, conditions and perspectives of their individual personal and professional development.

The special place in this process belongs to higher education that is intended to training pedagogical personnel "able to work in new conditions on new modern technologies" [2, p.329]. The competitiveness of staff in the system "person person" is mostly defined by their communicative competence. Hence in all links of the continuous education of the republic the problem of communicative culture development and improvement of future specialists "regarding modern tendencies of the development subject - subject interaction at pedagogical higher institution" is actively solved [ 3, p.3].

Training the students and future teachers to effective communication has a profound sociopersonal sense and great professional-pedagogical value. There is a necessity to scientific based pedagogical approaches to the problem solution.

The need of special investigation of the given problem is confirmed by the results of our conducted ascertaining experiment among the students of several pedagogical institutions of the republic to reveal their level of communicative culture development including pedagogical. The tasks of the experiment were determined as follow: to define how students as future teachers realize the main values, norms and traditions of communicative culture, its socio-personal sense and professional-pedagogical value; to reveal if the students realize the significance of knowledge of communication bases and practices, its technologies and techniques in the communication culture including pedagogical, its efficiency in personal, socio-public and professionalpedagogical levels, how often they participate in different socio-communicative events, if they work at self-perfection in this sphere, etc.

The results of both experimental and control groups on all criteria indicators (motivational, cognitive, technological, and reflexive) showed that communicative and rhetorical skills of the students were on the low and medium level. 
The analysis of scientific-pedagogical experience on the solution of the given problem in the foreign practice shows that, firstly, there worked out problems of training future specialists to effective communication in modern communicative conditions attracting the specialists of different directions: psychology of communication (B.F.Lomov, 1984; R.Verderber and K.Verderber, 2003; E.I.Rogov, 2005; G.M.Andreyeva, 2006; A.I.Volkova, 2007; E.P.Ilyin, 2009); philosophical view of the problem (M.S.Kagan, 1988; V.I.Fefelova, 2007); pedagogical communication (A.V.Mudrik, 1981; V.A.Kan-Kalik, 1987; A.A.Leontyev, 1989; V.N.Kunitsina et.al., 2001; V.M.Tseluyko, 2007; I.A.Kolesnikova, 2007).

Secondly, the search of the most effective systems, technologies for the perfection the work on developing communicative competence at future teachers is proceeding in the pedagogical science and practice. In the foreign practice for this purpose, socio-psychological trainings are actively implemented into educational-cultural process of educational institutions (L.A.Petrovskaya, 1989; D.Lewis, 2002; O.A.Galstyan, 2007). The main point of these active trainings is to provide sociopsychological effect on personality contributing to the development of their communicative competence.

A perspective direction is developing in the Russian pedagogical science as Professional Pedagogical Rhetoric (A.K.Mikhalskaya, 1998; T.A.Ladidjenskaya, 1999; N.A.Ippolitova, 2006; Z.S.Smelkova, 2012, et.al.). There are being designed theoretical and methodological bases of effective and of full value speech training of future specialists whose professional activity is also linked with the sphere of higher speech responsibility.

In general the problems of communication, training of pedagogical personnel to effective professional activity occupy a deserving place in the field of research interests of researchers-teachers in Uzbekistan. In the domestic investigations more attention is given to developing culture of speech activity of future pedagogical personnel (K.F.Kamalova， 1995; G.Kh.Jumasheva， 1996; M.E.Jumaev, 1999; B.Rakhimov, 2002; M.Yu.Makhkamova, 2002; et.al.).

Our investigation is dedicated to pedagogical opportunities of perfection of training students, future teachers to effective communication (on the level of technology and techniques) in the example of extracurricular activities on the subject of "Art of Communication". The aim of out of class activities is profound mastering of theory and practice of communication, its technologies and techniques causing effective communication; perfection of pedagogical communication by the students.

The training of future teachers to effective communication is fulfilled according to the following criteria:
I. Realization of the role and value of the communication bases and practice, its technologies and techniques in the culture of communication, including pedagogical, its efficiency on the personal, socio-public and professional-pedagogical levels.

II. Knowledge of bases: 1. Communication (in general) 2. Pedagogical communication 3. Verbal communication 4. Nonverbal communication 5 . Communication technology 6. Communication technique 7. Criteria of communication efficiency.

III. Performance of tasks, reports (essays), pedagogical and other intellectual-creative works on: 1. Communication bases 2. Pedagogical communication 3. Verbal communication means 4. Nonverbal communication means 5. Communication technologies 6. Communication techniques 7 . Communication efficiency.

IV.P a r t i c i p a t i o n:

1. In practical work, close to real sociocommunicative conditions (with the rational technological approach requirement to different types of communication and the wise use of its technology)

2. The social and communicative activities/events, followed by self-esteem, selfsatisfaction (or dissatisfaction) effective communication (interpersonal, group, public).

V. Self-perfection: 1. Communication culture 2. Pedagogical communication 3. Communication technologies 4.Communication techniques.

Criterial bases of training students to effective communication determine systematic-pedagogical approach to the problem solution in general. The main components of technology of students training to effective communication are:

I. Motivational training of students.

II. Mastering by the students, future teachers the required cognitive information (on communication bases, its means, technologies, techniques and criteria of effective communication).

III. Cognitive-forming stage - the fulfillment of tasks and work (intellectual-creative, pedagogical and methodological - on the bases of communication, pedagogical communication, verbal and nonverbal communication means, technologies and techniques of communication, its efficiency) by the students.

IV. Theoretical-practical activities, trainings, practical works (exercises, tries, rehearsals etc.), seminars, students' conferences, approximating students to real socio-communicative conditions (in active relation with technology and technique of effective communication). With self-esteem of efficiency their socio-communicative "debut".

VI. Students' self-perfection the culture of communication (with appropriate advice).

Criteria of training pedagogical institutions students and systematic approach to the given training are related with the program of 


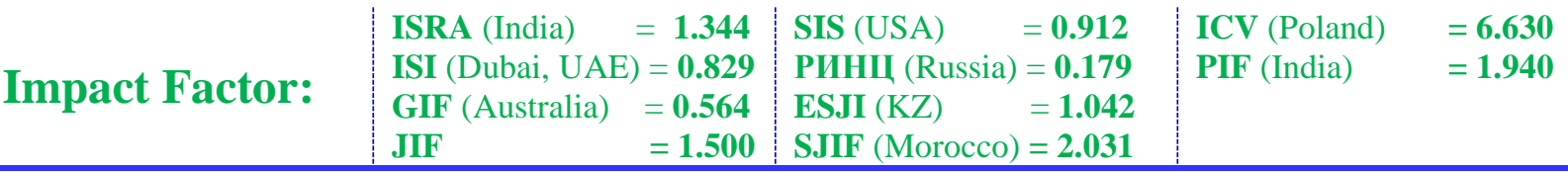

extracurricular activities on the subject "Art of communication" [4].

It is recommended to use the following generaltechnological construction:

I. Targetting and realization of the theme by the students, its motivational awareness.

II. Profound knowledge of students: 1. The essence of communication. 2. Aims, specificity, features, functions, aspects, principles, algorithms, types, styles of communication; tact, etiquette, ethics and aesthetics of communication. 3. Means of communication - verbal and nonverbal. 4. Communication as a process. 5. That is what is happening to the partner in the process of communication. 6. Interpersonal communication. 7. Pedagogical communication (on the base of the received information). 8. Conditions that supply effective communication - educational (extracurricular) and social-communicative practice (with the usage of its optimal technology and technique on the ethic and aesthetic level). In independent and public assessment.

III. Releasing to students, future teachers effective communication as a factor of personal development, its social activity and professional success.

The main stage of the experimental research, i.e. cognitive-informative and formative experiment was the subject to purposefulness, technology of (general and specific-subjective) communication, content of lectures-talks (or plan-thesis, short text material, used methods, techniques and tasks), with the analysis of criteria results (in tables), their quantitative and qualitative features.

Thus as examples of experimental lessons the following were identified: lecture-talks: "Communication", "Verbal means of communication", "Nonverbal means of communication"; theoretical-practical lessons "Technology of communication"; practical "Communication technique, its elements and reading them"; seminar - "Communication efficiency, the role of communication technology and technique in its productiveness".

The special section and constantly repeated question for more profound mastering was denoted pedagogical communication, for instance its technology and techniques as professionally significant for real communicative activity of the future teachers. In this respect there were received good results from the experiment groups.

One of the most important aspects of the theoretical-practical solution of the problem is theoretical-practical lessons, especially on the effective communication technology. There are solved theoretical-practical issues on the basis of communication, its theory and practice, technological tasks on resolving different communicative situations including pedagogical. There theoretical-practical works (according to the choice and interest) are carried out with the priority of technological approach to communication that contribute to its effectiveness.

We consider that mastering the speech techniques: voice, its sounding, diction, intonation, timbre, power; especially nonverbal techniques: mimes, gestures, movement, position of the hands, feet, figure, posture, manners and even appearance are very essential in training students to effective communication.

We also envisage interpretation of nonverbal elements of communication in the complex (of 11 tables proposed to the students) according to the author's methodology that promotes active correct perception of "the body language", reading of emotional signals, in their totality as well [5, p.47]. In the series of practical trainings the aim is achieved: specific and general picture of nonverbal communication, "penetration" into the mind and feeling, emotional state of the partner on dialogue, talk. The students realize the role and essence of communication technique in its efficiency (in the example of real variants of communication techniques, a number of pictures - portraits, groups of people).

The final stage of training students to communication, technology and technique of effective communication is a seminar on the problem "The role of technology and technique of communication in its efficiency" where the students make report on their theoretical and practical trainings, their implementation into socialcommunicative activity (in the form of theoreticalpractical materials, reports, talks, lectures and other intellectual-creative materials on the themes of previously or newly conducted out of class activities with their defense in front of their teachers and course-mates).

Reading "Carnegie" (on communication) and "Pedagogics" (on pedagogical communication) are practiced. There occurs a certain socialization of knowledge, skills and abilities acquired on the bases of communication, its theory and practice, technology and techniques.

It should be particularly noted that in all stages of training students to communication, its technology and techniques, effective communication, in the process of performing the tasks and different types of work on the topics of lectures, discussions, theoretical-practical and practical lessons and, of course, in preparation for the seminar, "Reading", the conference, the students are focused on the relevant literature and methods of implementation of intellectual and creative "products". In addition, for these purposes (and at the request of students) there constantly worked "advisory service". 


\begin{tabular}{|c|c|c|c|c|c|c|}
\hline Impact Factor: & $\begin{array}{l}\text { ISRA (India) } \\
\text { ISI (Dubai, UAF } \\
\text { GIF (Australia) } \\
\text { JIF }\end{array}$ & $\begin{array}{l}=1.344 \\
=0.829 \\
=0.564 \\
=1.500\end{array}$ & $\begin{array}{l}\text { SIS (USA) } \\
\text { PИНЦ (Russia) } \\
\text { ESJI (KZ) } \\
\text { SJIF (Morocco) }\end{array}$ & $\begin{array}{l}=0.912 \\
=0.179 \\
=1.042 \\
=2.031\end{array}$ & $\begin{array}{l}\text { ICV (Poland) } \\
\text { PIF (India) }\end{array}$ & $\begin{array}{l}=6.630 \\
=1.940\end{array}$ \\
\hline
\end{tabular}

Table 1

Results of training the students to the technology and technique of effective communication after participating in the practical works and social-communicative activities in \%.

\begin{tabular}{|c|c|c|}
\hline \multirow{3}{*}{ Criteria } & experimental & Control \\
\hline & 150 students & 150 students \\
\hline & \multicolumn{2}{|c|}{ On the main stage before/after the experiment } \\
\hline I. & $84 / 92$ & $40 / 48$ \\
\hline $\begin{array}{ll}\text { II. } & 1 . \\
& 2 . \\
& 3 . \\
& 4 . \\
& 5 . \\
& 6 . \\
& 7 . \\
\end{array}$ & $\begin{array}{c}72 / 86,66 \\
80 / 89,33 \\
76,66 / 84 \\
78,66 / 82,66 \\
81,33 / 85,33 \\
84 / 90,66 \\
80 / 84 \\
\end{array}$ & $\begin{array}{c}32 / 40 \\
44 / 46,66 \\
26 / 66 / 33,33 \\
30,66 / 41,33 \\
37,33 / 40 \\
36 / 42,66 \\
22 / 26 \\
\end{array}$ \\
\hline \multirow[t]{2}{*}{ III. } & $100 / 100$ and more & $44 / 49,33$ \\
\hline & \multicolumn{2}{|c|}{ Initial before/after the experiment } \\
\hline $\begin{array}{ll}\text { IV. } 1 . \\
2 .\end{array}$ & $\begin{array}{c}/ 100 \\
28 \text { without self-assessment/84 }\end{array}$ & $\begin{array}{c}-/ 44 \\
26,66 \text { without self-assessment /36 }\end{array}$ \\
\hline $\begin{array}{ll}\text { V. } 1 . \\
\\
2 . \\
3 . \\
4 .\end{array}$ & $\begin{array}{c}22 / 81,33 \\
30,66 / 86,66 \\
-/ 80 \\
-/ 73,33\end{array}$ & $\begin{array}{c}20,66 / 32 \\
32 / 46,66 \\
-/ 28 \\
-/ 29,33\end{array}$ \\
\hline
\end{tabular}

We can consider from the table №1 that in the experimental groups for all criteria indicators, particularly on the use of technology and technique of communication by the students, for its effective result, the quantitative data is quite satisfactory: the tasks and the intellectual and creative work are carried out by all students (in the control groups $49.33 \%$ of students); all the students of the experimental groups are actively involved in practical works (in the control group - 44\% of students); $84 \%$ of students in the experimental groups are involved in social and communication activities at various levels of communication (in the control group - $36 \%$ of students). Especially the students of the experimental groups are participating actively and qualitatively in the demonstration of their knowledge, skills, sub-skills and abilities in the technological approach to communication (its planning) and technique of communication (verbal and nonverbal), exposing these achievements to objective self-assessment, the main criterion of which is achieving the goal, efficiency (productivity) of communication and satisfaction with it.

In the end of the experimental research the students are offered a control interview on the following questions: 1. Kinds, types and styles of communication. 2. What is communication efficiency? 3. The conditions of communication efficiency. 4. What is communication technology? 5.
Communication technology and its efficiency. 6 . What is communication technique? 7. Verbal communication technique. 8. Nonverbal communication technique. 9. Body language elements. 10. How "to read" "the body language"? 11. Communication technique and its efficiency. 12. How do you think, if the technology and technique of communication are the key factors of its efficiency?

We should note that the students of the experimental groups answered the controlling questions deeply enough and in great detail, basing on the information on the art of communication in real-world examples, even from their own communication activities, the knowledge gained in the course of counseling sessions. In the control groups, this interview was not so satisfactory.

The table №2 shows the phased dynamics of high enough efficiency in the experimental groups in comparison with controlled groups, especially on the main criteria of the given training students integration of the theory of communication, its technology and technique into practice, particularly social-communicative (see the experimental results of the third stage in comparison with the controlled groups). There was realized the necessity of selfperfection in communication, especially its technologies and techniques, and of course peadagogical communication (see the experimental results of the fourth stage in the comparison with 


\begin{tabular}{|c|c|c|c|c|c|c|}
\hline Impact Factor: & $\begin{array}{l}\text { ISRA (India) } \\
\text { ISI (Dubai, UAE } \\
\text { GIF (Australia) } \\
\text { JIF }\end{array}$ & $\begin{array}{l}=1.344 \\
=0.829 \\
=0.564 \\
=1.500\end{array}$ & $\begin{array}{l}\text { SIS }(\text { USA) = } \\
\text { PИHЦ (Russia) }= \\
\text { ESJI (KZ) = } \\
\text { SJIF }(\text { Morocco) }=\end{array}$ & $\begin{array}{l}=0.912 \\
=0.179 \\
=1.042 \\
=2.031\end{array}$ & $\begin{array}{l}\text { ICV (Poland) } \\
\text { PIF (India) }\end{array}$ & $\begin{array}{l}=6.630 \\
=1.940\end{array}$ \\
\hline
\end{tabular}

controlled groups), that show quite high level of activity of the experimental group students to perfection of the communication culture.

The phased and final results of the experiments show the positive dynamics of the indicators growth of the mastering by the students the theory and practice of communication, its technology and technique, realizing of their role and essence in quite high efficiency of communication and especially pedagogical.

The results of experimental research are quite satisfactory (in comparison with controlled) that confirm its hypothesis, prove the accomplishment of the put aim, hence, the relevancy of the experimental program. In the issue of the theoretical-pedagogical and practical, experimental-pedagogical research the appropriate theoretical-pedagogical and practical positions, conclusions were formed that represent the bases of Pedagogics of the research problem solution; recommendations on training students to communication, its technology and technique were worked out that determine effective communication and as well as pedagogical.

The above mentioned positions, conclusions, recommendations, aims and other materials, especially of the practical research are quite effectively tested and implemented in a higher education practice.

The results of the phased training to effective communication technology and technique in

Table 2 extracurricular activities on "Art of communication" in \%.

\begin{tabular}{|c|c|c|c|c|c|c|c|c|c|c|}
\hline \multirow[b]{2}{*}{ : } & \multirow[b]{2}{*}{ 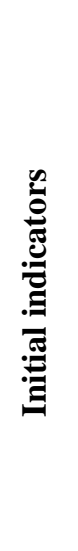 } & 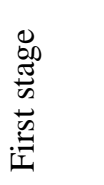 & 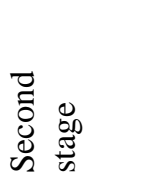 & 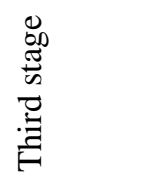 & 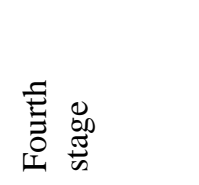 & & 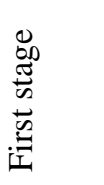 & 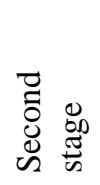 & 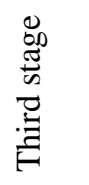 & 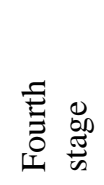 \\
\hline & & 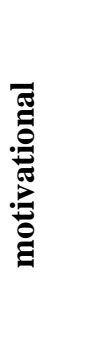 & 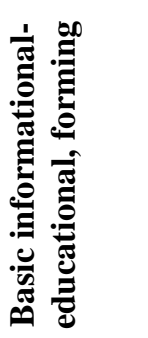 & 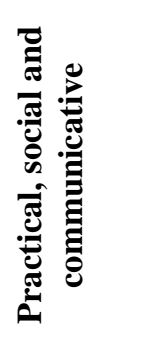 & 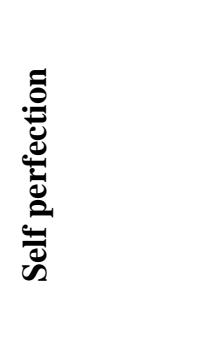 & 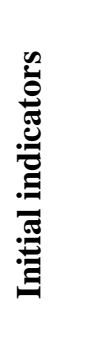 & 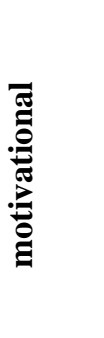 & 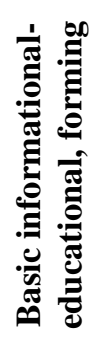 & 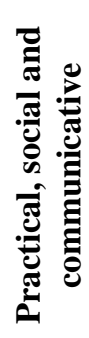 & 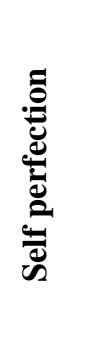 \\
\hline & \multicolumn{5}{|c|}{ In experimental groups } & \multicolumn{5}{|c|}{ In controlled groups } \\
\hline I. & 20,6 & 78,6 & 84 & 92 & 96 & 19,3 & 37,3 & 40 & 48 & 49,3 \\
\hline $\begin{array}{r}\text { II. } 1 . \\
2 . \\
3 . \\
4 . \\
5 . \\
6 . \\
7 .\end{array}$ & $\begin{array}{l}16 \\
26,6 \\
12 \\
6 \\
3,33 \\
6 \\
10\end{array}$ & $\begin{array}{l}36 \\
40 \\
32 \\
34,66 \\
33,33 \\
25,33 \\
36\end{array}$ & $\begin{array}{l}72 \\
80 \\
76,66 \\
78,66 \\
81,33 \\
84 \\
80\end{array}$ & $\begin{array}{l}86,66 \\
89,33 \\
84 \\
82,66 \\
85,33 \\
90,66 \\
84\end{array}$ & $\begin{array}{l}89,33 \\
92 \\
86,66 \\
85,33 \\
86,66 \\
93,33 \\
86,66\end{array}$ & $\begin{array}{l}16,66 \\
25,33 \\
13,33 \\
6,66 \\
4,6\end{array}$ & $\begin{array}{l}29,33 \\
36 \\
20,66 \\
28 \\
26,66 \\
23,33 \\
18\end{array}$ & $\begin{array}{l}32 \\
44 \\
26,66 \\
30,66 \\
37,33 \\
36 \\
22\end{array}$ & $\begin{array}{l}40 \\
46,66 \\
33,33 \\
41,33 \\
40 \\
42,66 \\
26\end{array}$ & $\begin{array}{l}2,66 \\
48 \\
41,33 \\
46,66 \\
45,33 \\
44 \\
36\end{array}$ \\
\hline III. & - & 44 & $\begin{array}{l}100 \text { and } \\
\text { more }\end{array}$ & $\begin{array}{l}100 \text { and } \\
\text { more }\end{array}$ & $\begin{array}{ll}100 & \text { and } \\
\text { more }\end{array}$ & - & 22 & 44 & 49,33 & 50,66 \\
\hline $\begin{array}{r}\text { IV.1. } \\
2 .\end{array}$ & $-\overline{28}$ & $\begin{array}{l}42,6 \\
36\end{array}$ & $\begin{array}{l}100 \\
80\end{array}$ & $\begin{array}{l}100 \\
84\end{array}$ & $\begin{array}{l}100 \\
92\end{array}$ & $-\overline{26,6}$ & $\begin{array}{l}25,3 \\
33,3\end{array}$ & $\begin{array}{l}44 \\
36\end{array}$ & $\begin{array}{l}45,3 \\
38,6\end{array}$ & $\begin{array}{l}52 \\
40\end{array}$ \\
\hline $\begin{array}{r}\text { V. } 1 . \\
2 . \\
3 . \\
4 .\end{array}$ & $\begin{array}{l}22 \\
30,6 \\
- \\
-\end{array}$ & $\begin{array}{l}29,3 \\
56 \\
32 \\
36\end{array}$ & $\begin{array}{l}81,33 \\
86,66 \\
80 \\
73,33\end{array}$ & $\begin{array}{l}86,66 \\
89,33 \\
82,66 \\
85,33\end{array}$ & $\begin{array}{l}89,33 \\
90,66 \\
86,66 \\
92\end{array}$ & $\begin{array}{l}20,6 \\
32 \\
- \\
-\end{array}$ & $\begin{array}{l}29,33 \\
41,33 \\
22 \\
25,33\end{array}$ & $\begin{array}{l}32 \\
46,66 \\
28 \\
29,33\end{array}$ & $\begin{array}{l}40 \\
48 \\
30,66 \\
36\end{array}$ & $\begin{array}{l}49,33 \\
56 \\
37,33 \\
48\end{array}$ \\
\hline
\end{tabular}




\begin{tabular}{l|lrl|l|ll} 
& ISRA (India) & $=\mathbf{1 . 3 4 4}$ & SIS (USA) & $=\mathbf{0 . 9 1 2}$ & ICV (Poland) & $=\mathbf{6 . 6 3 0}$ \\
Impact Factor: & ISI (Dubai, UAE) $=\mathbf{0 . 8 2 9}$ & PUHL (Russia) $=\mathbf{0 . 1 7 9}$ & PIF (India) & $=\mathbf{1 . 9 4 0}$ \\
& GIF (Australia) & $\mathbf{0 . 5 6 4}$ & ESJI (KZ) & $=\mathbf{1 . 0 4 2}$ & & \\
& JIF & $\mathbf{1 . 5 0 0}$ & SJIF (Morocco) $=\mathbf{2 . 0 3 1}$ & &
\end{tabular}

\section{References:}

1. Artomonova EI (2015) Podgotovka budushhego uchitelja $\mathrm{k}$ innovacionnoj dejatel'nosti: determinanty processa [ Training of future teachers to innovative activity: determinants of process]. Nauchnye trudy Mezhdunarodnoj konferencii Professionalizm pedagoga: sushhnost', soderzhanie, perspektivy razvitija [The professionalism of the teacher: the nature, content and prospects of development]. Proceedings of the International Conference. Moscow. MANPO, 2015. pp.3-10. (in Russian).

2. Karimov IA (1995) Myslit' i rabotat' po novomu trebovanie vremeni [To think and work in new ways the demand of the time]. Tashkent. Uzbekistan Publ., 1995, Vol .5.

3. Vitvickaja LA (2012) Razvitie vzaimodejstvija subektov obrazovatel'nogo processa universiteta: Avtoref. diss... dokt. ped. nauk. [Development of interaction of subjects of educational process of the University]. Orenburg, 2012.

4. Nurmanov AT (2014) Tehnologija podgotovki studentov $\mathrm{k}$ jeffektivnomu obshheniju. [Technology prepare students to communicate effectively]. LAP LAMBERT Academic Publishing, 2014. Available: http://www.lappublishing.com (Accessed: 20.12.2015). (in Russian).

5. Nurmanov AT (2010) Podgotovka studentov k tehnologii i tehnike effektivnogo obshhenija.
[To prepare students for the technology and art of effective communication] Tashkent., Fan va tehnologija Publ. 2010. (in Russian).

6. Grice HP (1975) Logic and conversation. In P. Cole and J.L. Morgan (Eds.), Syntax and semantics. Vol. 3. Speech 3 acts (pp.41-58). New York : Academic Press.

7. Bach K, Harnish RM (1979) Linguistic communication and speech acts. Cambidge, MA: MIT Press.

8. Verderber R, Verderber K (2003) «Psihologija obshhenija». [Communication psyhology]. SPb.: PRAJM- EVROZNAK. 2003.

9. Piz Alan, Garner Alan (2004) Jazyk razgovora [The language of conversation] -Moscow.: EKSMO, 2004.

10. Mihal'skaja AK (1998) Pedagogicheskaja ritorika: istorija i teorija:[Pedagogical rhetoric: history and theory]. Ucheb.posobie dlja studentov ped. Universitetov $\mathrm{i}$ in-tov. / A.K.Mihal'skaja.- Moscow: Izd. Centr «Akademija», 1998.

11. Mahkamova MJ (2002) Formirovanie pedagogicheskoj kul'tury obshhenija u budushhih vospitatelej. [Formation of pedagodical culture of communication of future teachers]. Avtoreferat diss. ...kand.ped.nauk.Tashkent. 2002. 